Proceeding Paper

\title{
Wind Energy Assessment during High-Impact Winter Storms in the Iberian Peninsula ${ }^{+}$
}

\author{
Ana Gonçalves ${ }^{1,2, *}$, Margarida L. R. Liberato ${ }^{2,3}$ and Raquel Nieto ${ }^{1}$ \\ 1 Environmental Physics Laboratory (EPhysLab), CIM-UVigo, Universidade de Vigo, 32004 Ourense, Spain; \\ rnieto@uvigo.es \\ 2 Instituto Dom Luiz, Faculdade de Ciências, Universidade de Lisboa, 1749-016 Lisboa, Portugal; mlr@utad.pt \\ 3 Escola de Ciências e Tecnologia, Universidade de Trás-os-Montes e Alto Douro, UTAD, Quinta de Prados, \\ 5000-801 Vila Real, Portugal \\ * Correspondence: ana.redondo.goncalves@uvigo.es \\ + Presented at the 3rd International Electronic Conference on Atmospheric Sciences, \\ 16-30 November 2020; Available online: https://ecas2020.sciforum.net/.
}

Citation: Gonçalves, A.; Liberato, M.L.R.; Nieto, R. Wind Energy Assessment during High Impact Winter Storms in the Iberian Peninsula. Environ. Sci. Proc. 2021, 4, 28. https://doi.org/10.3390/ecas202008132

Academic Editor: Anthony R. Lupo

Published: 13 November 2020

Publisher's Note: MDPI stays neutral with regard to jurisdictional claims in published maps and institutional affiliations.

Copyright: (c) 2020 by the authors. Licensee MDPI, Basel, Switzerland. This article is an open access article distributed under the terms and conditions of the Creative Commons Attribution (CC BY) license (http://creativecommons.org/licenses /by/4.0/).

\begin{abstract}
Electricity production through renewable energy sources, such as wind energy, is dependent on the variability of weather conditions. Thus, this work aimed to assess the wind resource available and the wind energy potential (WEP) during recent December months (the three years 2017, 2018, 2019). These winters were characterized by the occurrence of high-impact storms. To understand the effect of the strong winds associated with the passage of the storms during these months, we used $10 \mathrm{~m}$ wind components (10-m $\mathrm{U}$ and $\mathrm{V}$ wind components). The fields were extracted at 00, 06, 12, and 18 UTC (6-hourly data) for the 2017, 2018, and 2019 December months over a geographical sector that covers the Iberian Peninsula (IP) region ( $35^{\circ} \mathrm{N}-45^{\circ} \mathrm{N} ; 10^{\circ} \mathrm{W}-4^{\circ} \mathrm{E}$ ) and compared to climatological values for the 1981-2010 period. The obtained results showed an increase of wind intensity of up to $1.2 \mathrm{~m} \cdot \mathrm{s}^{-1}$ in IP during December 2017 and 2019 and a decrease of $1.2 \mathrm{~m} \cdot \mathrm{s}^{-1}$ in December 2018 when compared with the respective climatology for the 1981-2010 period. This increase corresponded to an increase in the corresponding WEP. Therefore, our results agreed with the values of the wind energy produced during the analyzed months for the two countries, Portugal and Spain. Finally, it is notable that the highest values of wind energy production occurred on the days of the storms' passage through the IP.
\end{abstract}

Keywords: renewable energy; wind energy; extreme events; high-impact storms; Iberian Peninsula

\section{Introduction}

The growing and continuing demand for renewable and clean energy, which allow for a significant reduction in greenhouse gas emissions, has increased in recent decades. However, it is necessary to understand the availability of the resources and their vulnerability to weather and climate conditions, as well as to climate change [1,2]. Wind energy is one of the fastest growing technologies in terms of production of renewable energy, and in recent years it has become increasingly attractive, presenting a successful economic development. The wind resource has proven to be a renewable, efficient, and clean energy source with a high potential for reducing greenhouse gas emissions [3].

The Iberian Peninsula (IP) - the two countries, Portugal and Spain - is one of the regions of the world with higher levels of installed wind power per capita and where wind energy plays a key role in the renewable energy mix [4]. In Spain, wind production remained the main renewable energy during the year 2019, with an installed capacity of 25,799 MW and representing $20.8 \%$ of total energy production [5]. In Portugal, wind energy has $5457 \mathrm{MW}$ of installed capacity [6] that contributes to $27.5 \%$ of total electricity 
generation, corresponding to 12.3 TWh [7]. Therefore, it is necessary to consider the meteorological and climatic variability when designing wind farms.

In this context, weather extreme events such as strong extratropical cyclones that originate in the North Atlantic and reach Europe are one of the major natural catastrophes in mid-latitudes, and the weather is primarily controlled by the passage of these systems and their associated fronts [8]. When events such as high-impact storms are extreme and persist across several days, they cause serious impacts on the sector of production and consumption. These are considered a serious risk for the power production sector of energy and its facilities, and they can cause disruption, lead to supply cuts, and affect other forms of infrastructure depending on the energy supply [9-11]. The rise in electricity production through renewable energy sources, such as onshore and offshore wind energy, also increases the sensitivity of energy systems to weather conditions and their variability. Therefore, it is crucial to consider the spatial and temporal variations in energy production and energy demand in the design and operation of power systems of renewable sources [12] in order to guarantee a continuous and secure energy supply in the future [13].

During the December months of 2017, 2018, and 2019, IP was affected by several highimpact storms that caused major adverse impacts [14-16]: in December 2017, three highimpact named storms (Ana, Bruno, and Carmen storms [14-16]); in December 2018, another three storms affected IP (Etienne, Flora [14,15], and Oswalde [17] or Deirdre [18]); and in the last considered December (2019), three additional storms (Daniel, Elsa, and Fabien storms $[14,15])$ affected IP with strong winds associated.

Thus, the objective of this study was to provide a first assessment of the available wind resource and wind energy potential (WEP) during the considered months of December $(2017,2018$, and 2019) and to understand the influence of high-impact storms in the production of electricity through wind energy technology.

\section{Data and Methods}

In order to analyze the wind resource availability and the wind energy potential during the 3 months of December $(2017,2018$, 2019), we retrieved the ERA5 Reanalysis 10 $\mathrm{m}$ wind components (10-m U and V wind components) from the European Centre for Medium Range Weather Forecasts (ECMWF) [19]. The fields were extracted at 00, 06, 12, and 18 UTC (6-hourly data) for the 2017, 2018, and 2019 December months over a geographical sector that covers the IP region $\left(35^{\circ} \mathrm{N}-45^{\circ} \mathrm{N} ; 10^{\circ} \mathrm{W}-4^{\circ} \mathrm{E}\right)$ and were compared to the climatological average of 6-hourly values for the December months of the 1981-2010 period.

The availability of the wind resource was assessed for each of the 3 months separately. For WEP calculations, ERA5 $10 \mathrm{~m}$ wind velocities $\left(V_{10}\right)$ were extrapolated to $135 \mathrm{~m}$, which is the considered hub height $(H)$ of onshore wind turbines widely installed in the IP, and it was used for this study [20]. The wind speed $(V)$ varies with altitude because of frictional effects at the surface of the earth. Therefore, we must correct for the wind speed at the presumed average hub height of the installed wind turbines [21]. For one to extrapolate measured wind speed to hub-height, there are several mathematical expressions to consider. Among these are the logarithmic law and the power law [22]. The logarithmic law is used here to characterize the impact of the roughness of the earth's surface on the windspeed, and it is expressed by the following equation:

$$
\frac{V}{V_{10}}=\frac{\ln \left(\frac{H}{Z}\right)}{\ln \left(\frac{H_{0}}{z}\right)}
$$

where $V$ is the windspeed at height $H, V_{10}$ is the windspeed at height $H_{0}$ (often a reference height of $10 \mathrm{~m}$ ), and $z$ is the roughness length coefficient [21,23]. The wind extrapolation is carried out assuming a logarithmic wind profile that assumes a neutrally stratified atmosphere [21]. This equation has been used in many studies of wind energy analyses [4,24-27] with different applications. In this study, the value of 0.03 was considered for the $z$ parameter. 
The power output of a wind turbine (Pout), or wind potential (WP), depends on air density (the standard near-surface value of $1.225 \mathrm{~kg} \cdot \mathrm{m}^{-3}$ ); turbine radius, $R(\mathrm{~m})$; wind speed, $V\left(\mathrm{~m} \cdot \mathrm{s}^{-1}\right)$; and rotor power coefficient, $C p$, which is the ratio of the rotor power density (mechanical power at the turbine shaft per unit of swept area) to the wind power density [28]. Between the turbine specific cut-in and rated wind velocity, the power output is proportional to the cubic power of wind speed:

$$
P_{\text {out }}=\frac{1}{2} C_{p} \rho \pi R^{2} V^{3}
$$

Hence, sensitivity of $P_{\text {out }}$ to wind speed is particularly high and depends on the power coefficients of a given turbine model [29]. The wind energy potential (WEP), or gross energy output $(E)$, for a period $(t)$ is calculated as

$$
\mathrm{WEP}=P_{\text {out }} \times t
$$

For this study, the turbine ENERCON of the model 4MW E-126 EP3 was used, and the characteristics are presented in Figure 1 [20,30].

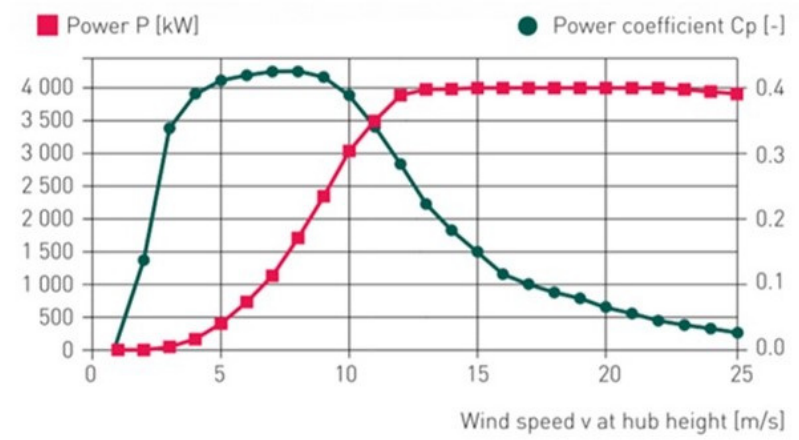

\begin{tabular}{ll}
\hline Rated power & $4000 \mathrm{~kW}$ \\
\hline Wind rated speed & $13 \mathrm{~m} \cdot \mathrm{s}^{-1}$ \\
\hline Rotor diameter & $127 \mathrm{~m}$ \\
\hline Cut-in velocity & $3 \mathrm{~m} . \mathrm{s}^{-1}$ \\
\hline Cut-out velocity & $25{\mathrm{~m} . \mathrm{s}^{-1}}$ \\
\hline
\end{tabular}

Figure 1. Power curve (in $\mathrm{kW}$ ) of the selected wind turbine (4 MW E-126 EP3, ENERCON) for wind speed ranging from 0 to over the cut-out velocity $\left(25 \mathrm{~m} \cdot \mathrm{s}^{-1}\right)$. Note the rated (maximum) power of $4000 \mathrm{~kW}$, wind rated speed of $13 \mathrm{~m} \cdot \mathrm{s}^{-1}(\mathrm{outlined}$ by the vertical dotted line), rotor diameter of $127 \mathrm{~m}$, and cut-in velocity of $3 \mathrm{~m} \cdot \mathrm{s}^{-1}$. Adapted from [20,30].

\section{Results and Discussion}

The analysis of the wind resource and wind energy potential (WEP) for the considered December months of 2017, 2018, and 2019 is presented in Figure 2 and Figure 3 , respectively.

To evaluate the wind resource availability in the December months of 2017, 2018, and 2019 and to understand how the wind resource varies spatially and temporally, we calculated the climatological average of the $10 \mathrm{~m}$ wind speeds for the month of December for the period 1981 to 2010 (Figure 2A). Then, respective anomalies were calculated for each of the considered years (Figure 2B-D). The mean wind speeds over IP ranged from 1.5 to $4.5 \mathrm{~m} \cdot \mathrm{s}^{-1}$. Thus, the obtained results showed an increase of wind intensity of up to $1.2 \mathrm{~m} \cdot \mathrm{s}^{-1}$ over the IP in onshore areas in December 2017 and 2019 (Figure 2B,D), but also in offshore areas (Atlantic Ocean on the north of IP and on Mediterranean Sea) where it reached more than $1.8 \mathrm{~m} \cdot \mathrm{s}^{-1}$. In Figure 2C, for December 2018, we verified a decrease of about $1.2 \mathrm{~m} \cdot \mathrm{s}^{-1}$ over the IP, and even larger on the Mediterranean Sea, where the difference reached $-2.4 \mathrm{~m} \cdot \mathrm{s}^{-1}$ when compared with the respective climatology for the 1981-2010 period.

Figure 3 presents similar results obtained for the WEP. The 30-year mean WEP was calculated for the December months of the period of 1981 to 2010 (Figure 3A) and for each of the December months in the analysis (Figure 3B-D). In the IP, the mean values of WEP ranged between 4 and $16 \mathrm{MWh}$ per day, and along the coastal areas and on offshore areas these can reach values of $32 \mathrm{MWh}$ per day, as is presented in Figure 3A. 

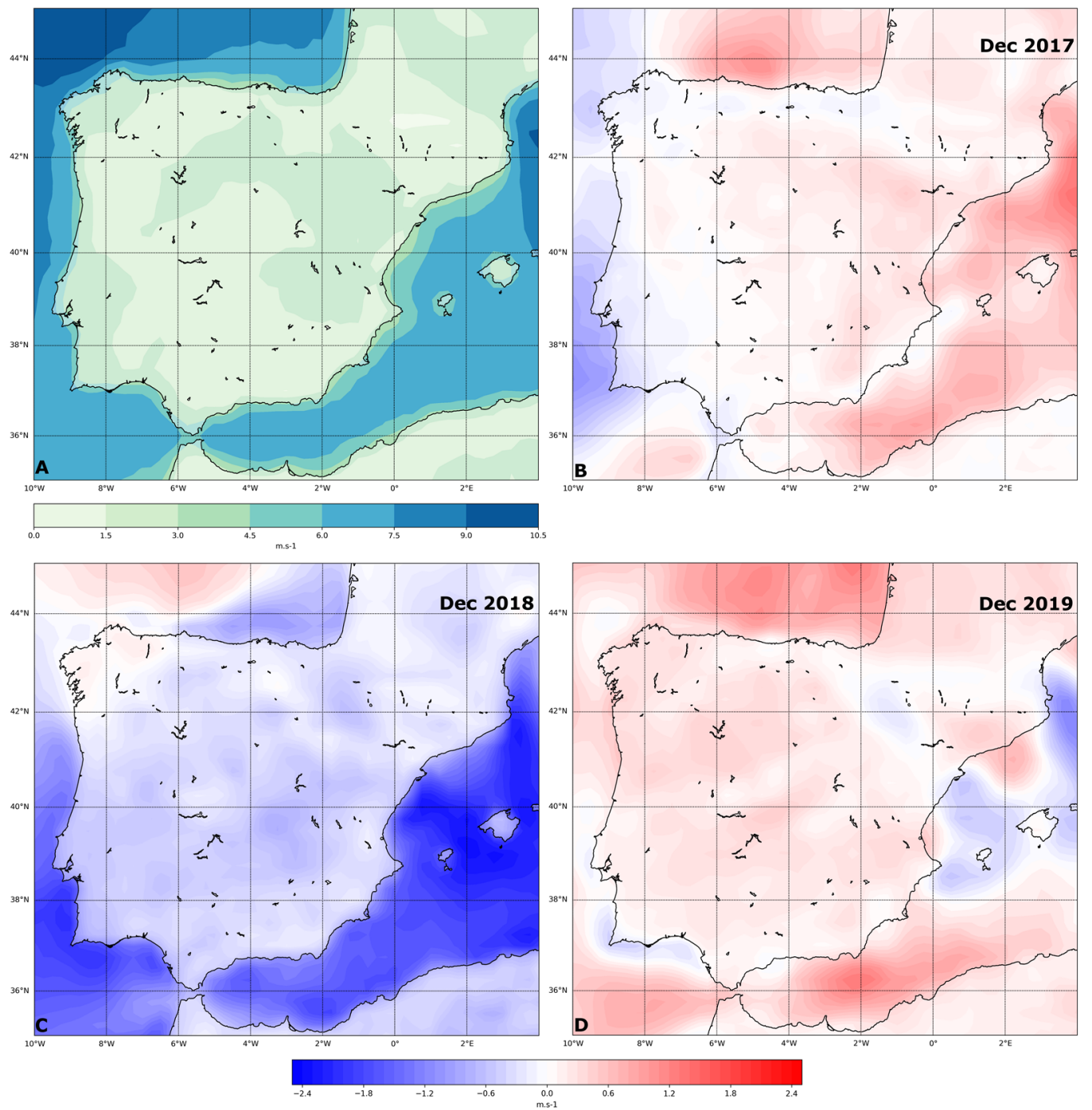

Figure 2. (A) Climatological average of ERA5 wind speed at $10 \mathrm{~m}\left(\mathrm{~m} \cdot \mathrm{s}^{-1}\right)$ for the December months of 1981 to 2010 . Anomalies of wind speed at $10 \mathrm{~m}\left({\left.\mathrm{~m} \cdot \mathrm{s}^{-1}\right)}\right.$ for December months of (B) 2017; (C) 2018; (D) 2019.

The obtained results for the anomalies show how the wind resource availability varies; in December 2017, the WEP over the IP had an increase of up to 6 MWh per day (Figure 3B). On offshore areas (Atlantic Ocean on the north of IP and on the Mediterranean Sea), this increase reached $9 \mathrm{MWh}$ per day (Figure 3B). In December 2019, there was also an increase of WEP over IP, with the values reaching $6 \mathrm{MWh}$ per day in practically the entire IP. In the offshore areas, there was a decrease in WEP in the eastern region of the Mediterranean Sea and in the entire north and south coast of the IP. It is worth noting the increase in production in the region of the Gibraltar strait, where the values reached up to more than 7 MWh per day. The month of December 2018 showed the lowest values of WEP, with values across the IP lower by up to $6 \mathrm{MWh}$ per day. In the offshore regions, those obtained were found to be lower up to -12 MWh per day over the Mediterranean Sea and on the southwest coast of Iberia.

These results are in agreement with the obtained values in Santos et al. [29] for the mean patterns of annual and winter months' (December, January, and February) WEP, where the highest values ranged from 8 to $16 \mathrm{MWh}$ per day on the northwest and north of IP region, on the southeast region of IP, and on the Gibraltar strait region. Moreover, while onshore daily WEP varies between 2 and 16 MWh per day, offshore values are never below $16 \mathrm{MWh}$ per day [29]. 

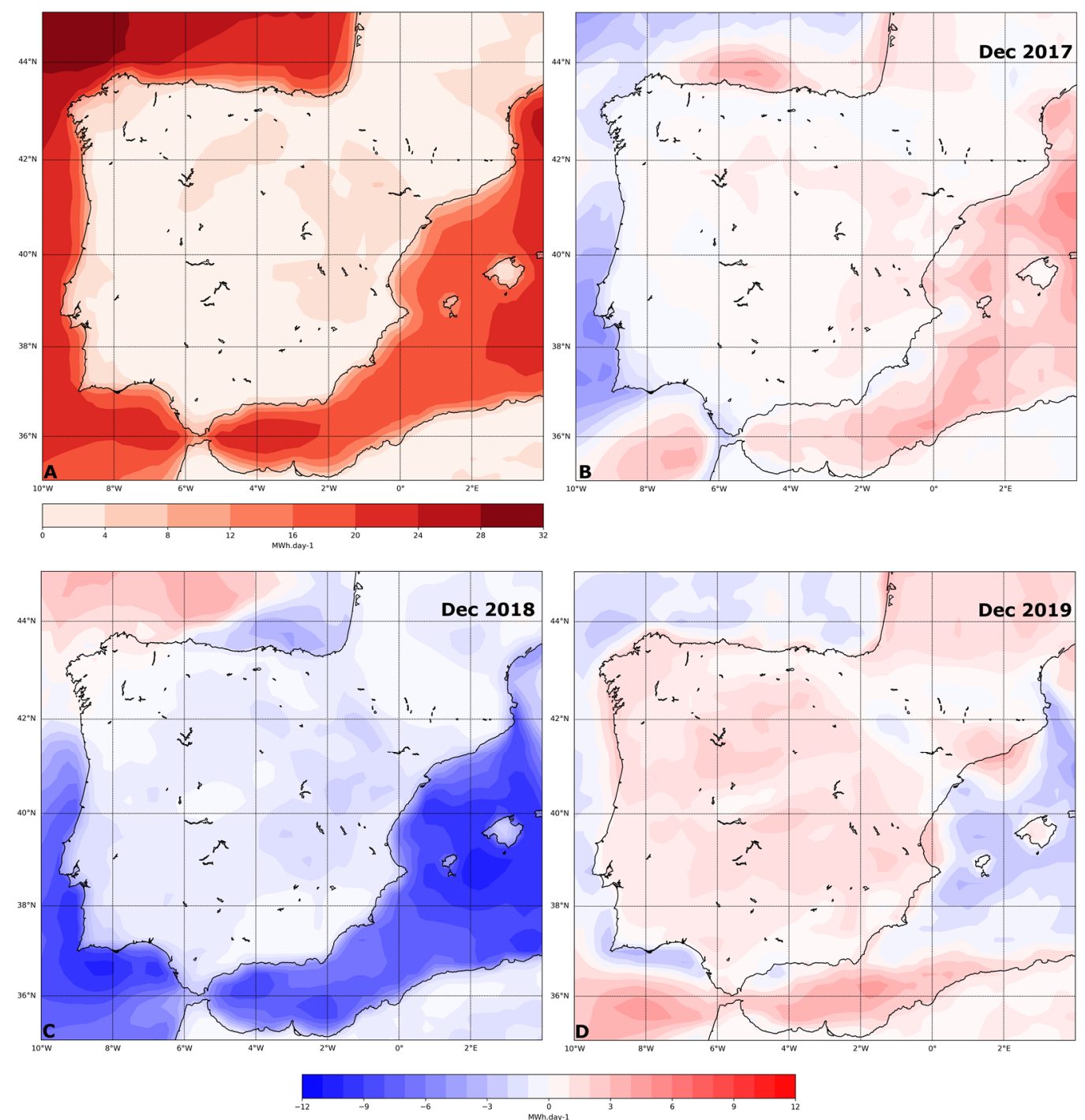

Figure 3. (A) Climatological average of wind energy potential (WEP) (MWh·day ${ }^{-1}$ ) for the December months of 1981 to 2010. Anomalies of WEP (MWh·day ${ }^{-1}$ ) for December months of (B) 2017; (C) 2018; (D) 2019.

When the electricity production reports were analyzed for December months in study, we found that the values obtained for mainland Portugal and for Spain (peninsular region) allowed us to confirm the results obtained in Figures 2 and 3.

In mainland Portugal, for December 2017, there was an increase in energy production compared to previous months. This increase was more accentuated with the passage of the two storms, on the 9th to the 11th of December, when the wind energy ensured renewable production with values from 2000 to $6000 \mathrm{MW}$. These high values of wind energy production were related to the passage of storm Ana during these days. On 26 December, we registered the monthly peak of renewable production, $7485 \mathrm{MW}$, at a time when the country was being affected by the storm Bruno. During the period when the storm Bruno affected mainland Portugal, renewable energies, especially wind energy, represented $105 \%$ of the country's electrical needs [31]. In Spain, wind was the technology that most contributed to the production of electricity in December 2017 (24.8\%), and on 27 December, the daily wind energy production had a share in the generation structure with a maximum of $44.7 \%$ during the passage of Bruno storm [32].

When analyzing December 2018 in mainland Portugal, we found a reduction in monthly wind productivity compared to previous months and compared to the values of the previous year [33]. In Spain, during the month of December of 2018, wind technology was the main source of production, representing $21 \%$ of total electricity production, for 
which wind energy reached $4.315 \mathrm{GWh}$, registering a - $25 \%$ variation compared to December 2017. The maximum production of wind energy in the peninsular Spain occurred on 13 December 2018 (with the occurrence of storm Flora), in which wind energy represented $35.9 \%$ of electricity production on that day. In addition to 13 December, on 16 December (Oswalde storm), there was a maximum of $52 \%$ coverage with wind production in the Spanish peninsular region [34].

In December 2019, the Portuguese renewable energy production was 77.2\% (4280 GWh), of which $27.4 \%$ corresponded to wind energy and $44.2 \%$ to hydroelectric production. These results reflected wind and water productivity far above the average during December, caused by the storms that occurred this month (Daniel, Elsa, and Fabien). This month, a new historical record was reached in renewable production, which corresponded to a consecutive period of five and a half days (uninterrupted period of $131 \mathrm{~h}$ ) between 18 and 23 December, when the production of renewable electricity was enough to satisfy consumption needs in mainland Portugal. In total, $331 \mathrm{~h}$ of $100 \%$ renewable consumption were recorded in December 2019 [7,35].

In December 2019, on the 12th, a new historic maximum of wind power was reached in the peninsular electricity system, with a value of 18,879 MW. On December 13 , the maximum daily wind energy was exceeded, reaching $397,541 \mathrm{MWh}$. The annual participation of wind energy in the peninsular production structure in 2019 was the highest recorded thus far and was the leading technology in the peninsular production structure in the months of January (25.5\%), May (23.5\%), November (34.0\%), and December (25.4\%) [36].

Thus, the reports of energy production confirm the trends of the obtained values with theoretical values of wind speed, and on the other hand they can prove that the highimpact storms had an influence on the electricity production of the IP. In December 2017 and 2019, we registered an increase of electricity production by wind energy, and in December 2018, there was a decrease [7,31-36].

\section{Conclusions}

Wind energy has an important role in the renewable energy mix of IP [10]. The installed capacity and the annual participation of wind energy in the energetic system of each country is higher, and this is an important and worthwhile point. These countries are betting, continuing to bet on wind energy to produce clean energy and reduce $\mathrm{CO}_{2}$ emissions.

Regarding the results obtained with the theoretical values, these were in line with the real values of electricity production from wind power in both countries, that is, an increase in production in the months of December of the year 2017 and 2019, and a decrease in December 2018. In addition, it was also confirmed that the occurrence of high-impact storms with associated strong winds has an influence on the resource available for energy production, since high values were obtained in the production of electricity with the passage of the storms. However, the data we have for this work did not allow us to verify whether the passage of the storms caused the cut-off of the wind turbines due to the high values of the wind speed and strong gusts with different directions. This fact can be discussed in a future work.

Funding: This work is supported by Fundação para a Ciência e a Tecnologia-FCT through the projects PTDC/CTA-MET/29233/2017 (WEx-Atlantic) and UID/GEO/50019/2020. The EPhysLab group is partially supported by the Xunta de Galicia under the project ED431C 2017/64-GRC Programa de Consolidación e Estructuración de Unidades de Investigación Competitivas (Grupos de Referencia Competitiva) and Consellería de Educación e Ordenación Universitaria, cofunding from the ERDF, in the framework of the Operational Program Galicia 2014-2020.

Conflicts of Interest: The authors declare no conflict of interest. 


\section{References}

1. Ravestein, P.; van der Schrier, G.; Haarsma, R.; Scheele, R.; van den Broek, M. Vulnerability of European intermittent renewable energy supply to climate change and climate variability. Renew. Sustain. Energy Rev. 2018, 97, 497-508, doi:10.1016/j.rser.2018.08.057.

2. Davy, R.; Gnatiuk, N.; Pettersson, L.; Bobylev, L. Climate change impacts on wind energy potential in the European domain with a focus on the Black Sea. Renew. Sustain. Energy Rev. 2018, 81, 1652-1659, doi:10.1016/j.rser.2017.05.253.

3. El Khchine, Y.; Sriti, M.; El Kadri Elyamani, N.E. Evaluation of wind energy potential and trends in Morocco. Heliyon 2019, 5, e01830, doi:10.1016/j.heliyon.2019.e01830.

4. Santos, F.; Gómez-Gesteira, M.; deCastro, M.; Añel, J.A.; Carvalho, D.; Costoya, X.; Dias, J.M. On the accuracy of CORDEX RCMs to project future winds over the Iberian Peninsula and surrounding ocean. Appl. Energy 2018, 228, 289-300, doi:10.1016/j.apenergy.2018.06.086.

5. RED Elétrica de España. Available online: https://www.ree.es/sites/default/files/11_PUBLICACIONES/Documentos/Renovables-2019.pdf (accessed on 7 September 2020).

6. Direção Geral de Energia e Geologia. Available online: https://www.dgeg.gov.pt/media/bbblbmb4/dgeg-arr-2020-07.pdf (accessed on 7 September 2020).

7. Associação de Energias Renováveis-APREN. Available online: https://www.apren.pt/contents/publicationsreportcarditems/boletim-energias-renovaveis-dezembro-2019-vf.pdf (accessed on 8 September 2020).

8. Catto, J.L.; Ackerley, D.; Booth, J.F.; Champion, A.J.; Colle, B.A.; Pfahl, S.; Pinto, J.G.; Quinting, J.F.; Seiler, S. The Future of Midlatitude Cyclones. Curr. Clim. Chang. Rep. 2019, 5, 407-420, doi:10.1007/s40641-019-00149-4.

9. Añel, J.A.; Fernández-González, M.; Labandeira, X.; López-Otero, X.; De la Torre, L. Impact of cold waves and heat waves on the energy production sector. Atmosphere 2017, 8, 209, doi:10.3390/atmos8110209.

10. Cronin, J.; Anandarajah, G.; Dessens, O. Climate change impacts on the energy system: a review of trends and gaps. Clim. Chang. 2018, 151, 79-93, doi:10.1007/s10584-018-2265-4.

11. Tobin, I.; Greuell, W.; Jerez, S.; Ludwig, F.; Vautard, R.; Van Vliet, M.T.H.; Breón, F.M. Vulnerabilities and resilience of European power generation to 1.5 C, 2 C and 3 C warming. Environ. Res. Lett. 2018, 13, 044024, doi:10.1088/1748-9326/aab211.

12. Zscheischler, J.; Westra, S.; Van Den Hurk, B.J.; Seneviratne, S.I.; Ward, P.J.; Pitman, A.; AghaKouchak, A.; Bresch, D.N.; Leonard, M.; Wahl, T.; et al. Future climate risk from compound events. Nat. Clim. Chang. 2018, 8, 469-477, doi:10.1038/s41558- 25 018-0156-3.

13. van der Wiel, K.; Bloomfield, H.C.; Lee, R.W.; Stoop, L.P.; Blackport, R.; Screen, J.A.; Selten, F.M. The influence of weather regimes on European renewable energy production and demand. Environ. Res. Lett. 2019, 14, 094010, doi:10.1088/17489326/ab38d3.

14. Instituto Português do Mar e da Atmosfera-IPMA. 2020. Available online: https://www.ipma.pt/en/index.html (accessed on 15 September 2020).

15. Agencia Estatal Meteorología-AEMet. 2020. Borrascas con Gran Impacto: Información Divulgativa y de Otras Temporadas. Available online: http://www.aemet.es/es/conocermas/borrascas (accessed on 15 September 2020).

16. Météo France. 2020. Available online: http://www.meteofrance.com/accueil (accessed on 15 September 2020).

17. Institut für Meteorologie. Met.fu-Berlin. 2020. Available online: http://www.met.fu-berlin.de/adopt-a-vortex/historie/ (accessed on 15 September 2020).

18. Met Office. Available online: https://www.metoffice.gov.uk/binaries/content/assets/metofficegovuk/pdf/weather/learnabout/uk-past-events/interesting/2018/storm-deirdre---met-office.pdf (accessed on 9 September 2020).

19. Hersbach, H.; Bell, W.; Berrisford, P.; Horányi, A.; Sabater, J.M.; Nicolas, J.; Radu, R.; Schepers, D.; Simmons, A.; Soci, C.; et al. Global reanalysis: Goodbye ERA-Interim, hello ERA5. ECMWF Newsl. 2019, 159, 17-24, doi:10.21957/vf291hehd7.

20. ENERCON - Energy for the World. Available online: https://www.all-energy.co.uk/_novadocuments/457177?v=63657233817 0430000 (accessed on 9 September 2020).

21. Hoogwijk, M.; de Vries, B.; Turkenburg, W. Assessment of the global and regional geographical, technical and economic potential of onshore wind energy. Energy Econ. 2004, 26, 889-919, doi:10.1016/j.eneco.2004.04.016.

22. Frank, C.W.; Pospichal, B.; Wahl, S.; Keller, J.D.; Hense, A.; Crewell, S. The added value of high resolution regional reanalyses for wind power applications. Renew. Energy 2020, 148, 1094-1109, doi:10.1016/j.renene.2019.09.138.

23. Masters, G.M. Renewable and Efficient Electric Power Systems. In Renewable and Efficient Electric Power Systems; John Wiley \& Sons: Hoboken, NJ, USA, 2004. doi:10.1002/0471668826.

24. Costoya, X.; deCastro, M.; Santos, F.; Sousa, M.C.; Gómez-Gesteira, M. Projections of wind energy resources in the Caribbean for the 21st century. Energy 2019, 178, 356-367, doi:10.1016/j.energy.2019.04.121.

25. Rogers, T.; Ashtine, M.; Koon Koon, R.; Atherley-Ikechi, M. Onshore wind energy potential for Small Island Developing States: Findings and recommendations from Barbados. Energy Sustain. Dev. 2019, 52, 116-127, doi:10.1016/j.esd.2019.08.002.

26. Ryberg, D.; Caglayan, D.; Schmitt, S.; Linßen, J.; Stolten, D.; Robinius, M. The future of European onshore wind energy potential: Detailed distribution and simulation of advanced turbine designs. Energy 2019, 182, 1222-1238, doi:10.1016/j.energy.2019.06.052.

27. Soares, P.M.M.; Lima, D.C.A.; Semedo, A.; Cabos, W. Climate Change Impact on Northwestern African Offshore Wind Energy Resources. Environ. Res. Lett. 2019, 14, 124065, doi:10.1088/1748-9326/ab5731. 
28. International Electro-technical Commission. Wind turbines Part 12-1: Power performance measurements of electricity producing wind turbines. IEC 61400-12-1 2005. (In Japanese)

29. Santos, J.A.; Rochinha, C.; Liberato, M.L.R.; Reyers, M.; Pinto, J.G. Projected changes in wind energy potentials over Iberia. Renew. Energy 2015, 75, 68-80, doi:10.1016/j.renene.2014.09.026.

30. ENERCON-Energy for the World. Available online: https://www.enercon.de/en/products/ep-3/e-126-ep3/ (accessed on 9 September 2020).

31. Associação de Energias Renováveis-APREN. Available online: https://www.apren.pt/contents/publicationsreportcarditems/12-boletim-energias-renovaveis--dezembro.pdf (accessed on 8 September 2020).

32. Rede Eléctrica de España - REE. Available online: https://www.ree.es/sites/default/files/11_PUBLICACIONES/Documentos/InformesSistemaElectrico/2017/inf_sis_elec_ree_2017.pdf (accessed on 8 September 2020).

33. Associação de Energias Renováveis-APREN. Available online: https://www.apren.pt/contents/publicationsreportcarditems/12-boletim-energias-renovaveis-2018.pdf (accessed on 8 September 2020).

34. Rede Eléctrica de España-REE. Available online: https://www.ree.es/sites/default/files/11_PUBLICACIONES/Documentos/ree_diciembre_2018.pdf (accessed on 8 September 2020).

35. Rede Elétrica Nacional-REN. Available online: https://www.ren.pt/pt-PT/media/comunicados/detalhe/producao_renovavel_abastece_51_do_consumo_em_2019_2 (accessed on 8 September 2020).

36. Rede Eléctrica de España - REE. Available online: https://www.ree.es/sites/default/files/11_PUBLICACIONES/Documentos/InformesSistemaElectrico/2019/inf_sis_elec_ree_2019.pdf (accessed on 8 September 2020). 